\title{
Surgical procedures implemented in Japan-Indonesia collaborative study of skin cancer
}

\author{
Evert Poetiray ${ }^{1}$, Arman Mukhtar $^{1}$, Masamitsu Ichihashi ${ }^{2}$, Mochtar Hamzah $^{3}$, Masato Ueda ${ }^{2}$, Sonar Panigoro ${ }^{1}$, \\ Mpu Kanoko ${ }^{4}$, Herman Cipto ${ }^{3}$, Achmad Tjarta ${ }^{4}$, Joedo Prihartono ${ }^{5}$, Setyawati Budiningsih ${ }^{5}$, Yoshiyuki Ohno ${ }^{6}$, \\ Nobuo Munakata ${ }^{7}$, Santoso Cornain ${ }^{4}$
}

\begin{abstract}
Abstrak
Kanker kulit kelihatan menjadi suatu masalah keganasan yang penting di Indonesia dan Jepang. Berdasarkan suatu kepentingan bersama dari masalah ini, maka dibentuk suatu studi gabungan antara Indonesia dan Jepang, mengenai tiga aspek tentang epidemiologi, klinik dan histopatologi, yang ditangani oleh 2 buah tim multidisiplin, dari Jepang dan Indonesia. Kami akan membahas hasil penelitian penyakit kanker kulit di Rumah Sakit Umum Pusat Nasional Dr. Cipto Mangunkusumo, mulai Agustus 1996 sampai 29 Maret 1999, dimana terkumpul 139 kasus, dengan jumlah terbanyak pada golongan usia diatas 60 tahun yaitu 78 kasus (56.1 \%). Bergantung pada diagnosis dan meluasnya keganasan, prosedur bedah yang diterapkan adalah amputasi dengan atau tanpa pengangkatan kelenjar getah bening, hemimaksilektomi dan eksisi lebar dengan atau tanpa pengangkatan kelenjar getah bening. Eksisi lebar dilakukan pada sebagian besar kasus (77,3\%), yaitu pada 87,9\% karsinoma sel basal, 66,7 \% karsinoma sel skuamosa dan 66,7 \% melanoma maligna. Selama penelusuran 2 tahun, tidak ditemukan kekambuhan.
\end{abstract}

\begin{abstract}
Skin cancer appeared to be an important cancer problem in Indonesian and Japan. Based on common interest of the problem, a joint study between Japan and Indonesia on Skin Cancer has been established. Three fold-study, namely epidemiological, clinical and histopathological aspects building of Multidisciplinary teams, for both the Japanese and the Indonesian sides. Here, we present the results of skin cancer examination in Dr. Cipto Mangunkusumo National Center General Hospital from August 1996 until March 29, 1999, with a total of 139 cases, with the peak at 6-decade age group, i.e. 78 cases (56.1\%). Depending on the diagnosis and the extent of the malignancy, the surgical procedures applied were amputation with or without lymph node dissection, hemimaxillectomy and wide excision with or without lymph node dissection. Wide excision was performed in the majority (77.3 \%) of cases, i.e. in $87.9 \%$ of basal cell carcinoma, $66.7 \%$ of squamous cell carcinoma and $66.7 \%$ of malignant melanoma. During 2 years follow up, no recurrence of the malignant lesion was observed.
\end{abstract}

Keywords: Skin cancer, Japan-Indonesia, collaborative study, surgical treatment

In the developed country such as the United States, skin cancers showed increased incidence. ${ }^{1-3}$ The

\footnotetext{
${ }^{I}$ Department of Surgery, Faculty of Medicine, University of Indonesia, Jakarta 10430, Indonesia

2 Department of Dermatology, Kobe University School of Medicine, Kobe 650-0017, Japan

3 Department of Dermatology, Faculty of Medicine, University of Indonesia, Jakarta 10430, Indonesia

4 Department of Anatomic Pathology, Faculty of Medicine, University of Indonesia, Jakarta 10430, Indonesia

5 Department of Community Medicine, Faculty of Medicine, University of Indonesia, Jakarta 10320, Indonesia

6 Department of Preventive Medicine, Nagoya University School of Medicine, Nagoya 466-8550, Japan

7 Radiobiology Division, National Cancer Center Research Institute, Tokyo 104-0045, Japan
}

problems of its morbidity remain important in spite of lower mortility for non-melanoma skin cancers. In terms of the detection of skin cancer, usually the patients themselves could recognize the tumors and visited the physician relatively early, so that they were treated at an early stage of malignancy. In Indonesia however, patients with skin cancer see doctors at the late stage of the disease, mainly due to ignorance of the patients and their family or the delay in seeking for medical help from the physician.

In 1992, the relative frequency of skin cancer for females is $6.35 \%$, ranked the $4^{\text {th }}$ among other tumors and the first in males $(11.21 \%){ }^{4}$ It has been reported that solar ultraviolet exposure caused increased risk of skin cancer in various countries, including Japan. ${ }^{1-3,5,6}$ 
Similar data has been obtained in our Japan-Indonesia Collaborative Study. ${ }^{7}$ If the ozone depletion continues at the Antarctic and also extend to the equatorial area in the future, the increasing number of cancer in Indonesia may become a social concern to be solved. Therefore, our ongoing epidemiological case-control study was also accompanied by direct measurement of the solar ultraviolet-B using biological method (spore dosimetry) in various parts of the country, i.e. Jakarta, Padang, Yogyakarta and Denpasar. So far, the results indicated that the uv-B strength in Jakarta and Denpasar was about three to five times as high as in Tokyo. ${ }^{8}$ The findings are now being analyzed further in order to make better assessment of the ultraviolet risk for the development of skin cancer relative to geographical (latitude) and ethnical difference (skin type).

In the present study, we aimed to clarify the clinical characteristics of skin cancer treated in Department of Surgery, applying specific surgical procedures adjusted for individual case according to the stage of the tumor at the admission to the hospital. The present paper is to discuss the efficacy of the most common treatment applied to the Indonesian skin cancer patients and some problems encountered.

\section{MATERIALS AND METHODS}

\section{Clinicopathological characterization of skin cancer cases for determining surgical treatment}

Skin cancer patients enrolled to the Japan-Indonesia Joint Study on Etiology and Clinicopathology of Skin Cancer were patients who visited the Department of Dermatology and Department of Surgery of the Faculty of Medicine, University of Indonesia, from August 1996 to March 29, 1999. They were examined by well-trained dermatologists and surgeons during our study period, and diagnosed clinically at the first visit. Histopathological confirmation was established from the biopsy specimens sent to the Department of Pathology. Periodic evaluation was made both during the pilot study started from 1995 and during the definitive study from 1997 on for 3 years. Skin cancer patients with $1 \mathrm{~cm}$ or larger in diameter were treated by surgery. In order to characterize the clinical aspects and to evaluate the efficacy of the treatments, the patients were categorized according to age, sex and site of the skin cancer. The stage of the disease and the extent of the surgical procedure were taken into account for overall evaluation of the treatments.
Depending on such considerations, the type of surgical procedures were applied accordingly. The guidelines applied was modified from the one used in the preliminary study. ${ }^{9}$

\section{Surgical procedures of skin cancer}

Surgical treatment of both non-melanoma and melanoma skin cancer includes methods such as local excision, curettage and electrodessication, cryosurgery and Mohs micrographic surgery. The methods applied were both standard and modified surgical managements documented elsewhere. ${ }^{10-12}$ One centimeter margin of excision was determined for basal cell carcinoma (BCC) on the face, while $1.5-2 \mathrm{~cm}$ margin was applied to the $\mathrm{BCC}$ on the back. The margin of the excised tissue was examined by the pathologist for detecting any remaining tumor cells, starting from the closest margin near the tumor border to the edge of clinically/ macroscopically normal skin. If the extreme end of the tissue was free from tumor cells, reconstruction of the mutilated area was performed. When there were tumor cells in or adjacent to the border of the tissue, re-excision was done until the pathological report was negative from tumor cells. If the surgery might cause mutilation, radiotherapy was applied. In Dr. Cipto Mangunkusumo Hospital, Jakarta, skin cancers with a diameter of $1 \mathrm{~cm}$ or larger were treated in the Department of Surgery and those with diameter less than $1 \mathrm{~cm}$ were treated in the Department of Dermatology.

For the management of squamous cell carcinoma (SCC) and malignant melanoma (MM) patients, wide excision with $3 \mathrm{~cm}$ margin was a common procedure in Indonesia.

For preventing further growth of primary skin cancer, surgical dissection was applied to the first regional lymph nodes, if any palpable enlarged lymph node was pathologically containing tumor cells. Such lymph node was removed surgically (therapeutic lymph node dissection).

Another application of surgical removal was to excise a single, slow growing metastatic lesion and also to prepare circulation system for isolated regional perfusion of anti cancer agents, after excising a melanoma lesion of the extremity.

The schemes for biopsy procedures are given in Figures 1 \& 2 for both vertical and horizontal orientation. 


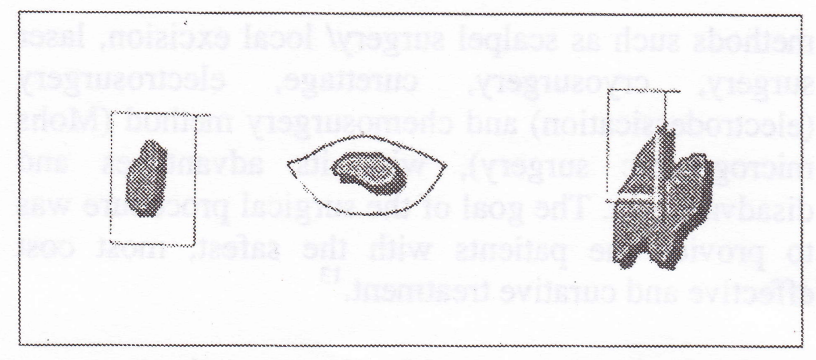

Figure 1. Biopsy scheme depending on the size and the depth of skin cancer (in vertical orientation)

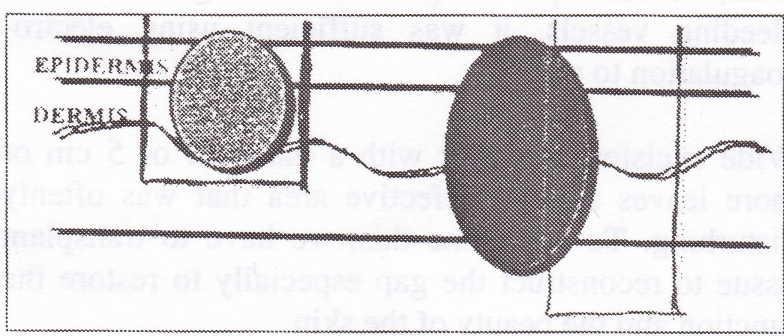

Figure 2. Biopsy scheme depending on the size and the width of skin cancer (in horizontal orientation)

\section{RESULTS}

A total of 139 cases of skin cancer were collected in the Departments of Surgery and Dermatology during study period of January 1996 to March 1999. The age distribution of 139 cases is given in Table 1. The frequency distribution according to age was also depicted in Figure 3, showing normal distribution with mean age of $58.8 \pm 13.5$ years.

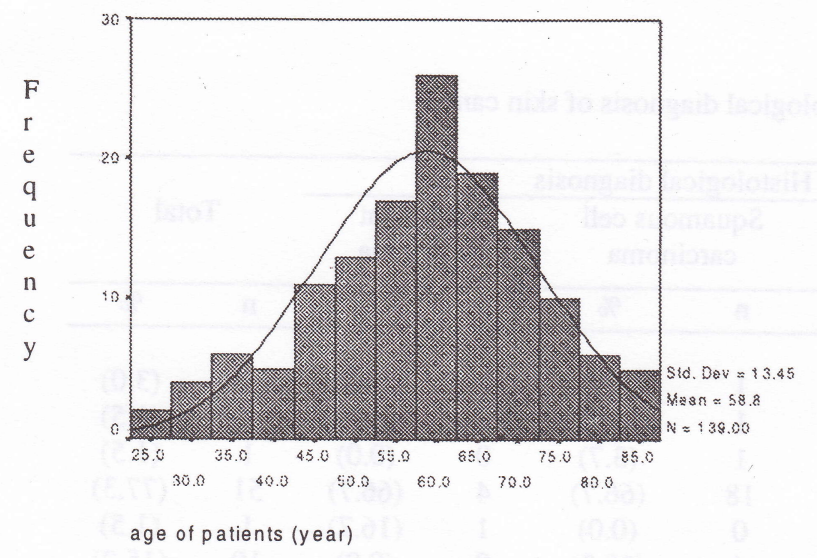

Figure 3. Age distribution of all skin cancer cases collected in the Departments of Dermatology and Surgery, from January 1996 to March 1999.
Table 1. Age distribution of all skin cancers $(n=139)$ collected at Departments of Dermatology and surgery from 1996 to 1999

\begin{tabular}{ccc}
\hline Age group & \multicolumn{2}{c}{ Frequency of cases } \\
\cline { 2 - 3 } & $\mathrm{n}$ & $(\%)$ \\
\hline $20-29$ & 2 & $(1.4)$ \\
$30-39$ & 10 & $(7.2)$ \\
$40-49$ & 19 & $(13.7)$ \\
$50-59$ & 30 & $(21.6)$ \\
$60-69$ & 45 & $(32.4)$ \\
$70-$ & 33 & $(23.7)$ \\
\hline Total & 139 & $(100.0)$ \\
\hline
\end{tabular}

Table 2. Age distribution of skin cancers treated at Department of Surgery from 1996 to 1999

\begin{tabular}{ccc}
\hline Age group & \multicolumn{2}{c}{ Frequency of cases } \\
\cline { 2 - 3 } & $\mathrm{n}$ & $(\%)$ \\
\hline $20-29$ & 1 & $(1.5)$ \\
$30-39$ & 2 & $(3.0)$ \\
$40-49$ & 11 & $(16.7)$ \\
$50-59$ & 14 & $(21.2)$ \\
$60-69$ & 24 & $(36.4)$ \\
$70-$ & 14 & $(21.2)$ \\
\hline Total & 66 & $(100.0)$ \\
\hline
\end{tabular}

The majority $(77 \%)$ of the cases aged $50-70^{*}$ years or higher. The peak of skin cancer cases was in the $6^{\text {th }}$ decade, i.e. 45 ( $32.4 \%$ ) cases. Among them 66 cases were treated at the Department of Surgery. Thirty six were males and 30 were females. The age distribution of the surgical treated cases is given in Table 2. Similarly, the majority $(78.8 \%)$ of the cases aged 50 - 70 years or higher. Histologically, they were diagnosed as BCC in $33(50.0 \%)$ cases, SCC in 27 $(40.9 \%)$ cases MM in $6(9.1 \%)$ cases.

The type of surgical procedures applied varied from amputation, amputation plus lymph node dissection, hemimaxillectomy, wide excision, wide excision and lymph node dissection. The majority, i.e. 51 (77.3\%) cases were treated by wide excision only and combination with lymph node dissection in 1 case, while the rest was treated by amputation in 2 cases, amputation plus lymph node dissection in 1 case, hemimaxillectomy in 1 case. The details are given in Table 3. Ten cases were not treated either due to cancellation, refusal or inoperable status. 
Twenty nine $(87.9 \%)$ out of 33 cases of BCC were widely excised, with only 1-2 cm margin in most of the cases, while in 5 cases, the excision was followed by reconstruction due to the wide loss of normal skin. Four cases $(12.1 \%)$ were not treated by surgery. Wide excision was also applied to the majority of SCC, i.e. in $18(66.7 \%)$ out of 27 cases. Three cases were treated by amputation, amputation plus lymph node dissection and hemimaxillectomy, respectively. Six cases $(22.2 \%)$ were untreated surgically.

Four $(66.7 \%)$ out of 6 cases of melanoma were treated with wide excision alone and 1 case was widely excised plus lymph node dissection. The other 1 case was amputated.

Table 3. Frequency distribution of type of surgical procedures in skin cancer

\begin{tabular}{llcc}
\hline & Surgical procedures & \multicolumn{2}{c}{ Frequency of cases } \\
\cline { 2 - 3 } & & $\mathrm{n}$ cases & Percentage \\
\hline 1. & $\begin{array}{l}\text { Amputation } \\
\text { 2. Amputation \& lymph }\end{array}$ & 2 & $(3.0)$ \\
& $\begin{array}{l}\text { node dissection } \\
\text { 3. }\end{array}$ & 1 & $(1.5)$ \\
4emimaxillectomy & 1 & $(1.5)$ \\
5. Wide excision & $\begin{array}{l}\text { Wide excision \& lymph } \\
\text { node dissection }\end{array}$ & 51 & $(77.3)$ \\
6. $\begin{array}{l}\text { Canceled/ Refused/ } \\
\text { Inoperable }\end{array}$ & 1 & $(1.5)$ \\
\hline \multicolumn{2}{c}{ Total } & 10 & $(15.2)$ \\
\hline
\end{tabular}

\section{DISCUSSION}

The first choice applied in the treatment of skin cancer was surgery. Treatments of skin cancer includes methods such as scalpel surgery/ local excision, laser surgery, cryosurgery, curettage, electrosurgery (electrodessication) and chemosurgery method (Mohs micrographic surgery), with its advantages and disadvantages. The goal of the surgical procedure was to provide the patients with the safest, most cost effective and curative treatment. ${ }^{13}$

As for scalpel surgery, bleeding was the common disadvantage, but by carefully dissecting the tissue, identifying bigger blood vessels and tying and cutting them, we could prevent profuse bleeding. For smaller bleeding vessels, it was sufficient using electrocoagulation to stop it.

Wide excision of tumor with a diameter of $5 \mathrm{~cm}$ or more leaves a large defective area that was oftenly disturbing. To overcome this, we have to transplant tissue to reconstruct the gap especially to restore the function and the beauty of the skin.

For such conditions, the methods used were classic and simple. Besides that, the surgical margins could be examined directly by the pathologist to determine whether remaining tumor cells in/near the incision margin were found. The excision could be widened or irradiated after the wound healing, as needed.

Two major functions of scalpel surgery in the management of malignant tumor are in the fields of diagnosis and therapy. To establish the diagnosis i.e. benign or malignant, we need to take the whole tumor (excisional biopsy, if the tumor is small) or a piece of the tumor (incisional biopsy if the tumor is bigger, or in operable) with a bit of healthy tissue around the lesion so that the pathologist can examine the surgical

Table 4. Distribution of type of surgical procedures in relation to histological diagnosis of skin cancer

\begin{tabular}{|c|c|c|c|c|c|c|c|c|}
\hline \multirow{3}{*}{ Surgical procedures } & \multicolumn{6}{|c|}{ Histological diagnosis } & \multirow{2}{*}{\multicolumn{2}{|c|}{ Total }} \\
\hline & \multicolumn{2}{|c|}{$\begin{array}{l}\text { Basal cell } \\
\text { carcinoma }\end{array}$} & \multicolumn{2}{|c|}{$\begin{array}{l}\text { Squamous cell } \\
\text { carcinoma }\end{array}$} & \multicolumn{2}{|c|}{$\begin{array}{l}\text { Malignant } \\
\text { melanoma }\end{array}$} & & \\
\hline & $\mathrm{n}$ & $\%$ & $\mathrm{n}$ & $\%$ & $\mathrm{n}$ & $\%$ & $\mathrm{n}$ & $\%$ \\
\hline 1. Amputation & 0 & $(0.0)$ & 1 & $(3.7)$ & 1 & $(16.7)$ & 2 & $(3.0)$ \\
\hline 2. Amputation \& lymph node dissection & 0 & $(0.0)$ & 1 & $(3.7)$ & 0 & $(0.0)$ & 1 & $(1.5)$ \\
\hline 3. Hemimaxillectomy & 0 & $(0.0)$ & 1 & $(3.7)$ & 0 & $(0.0)$ & 1 & $(1.5)$ \\
\hline 4. Wide excision & 29 & $(87.9)$ & 18 & $(66.7)$ & 4 & $(66.7)$ & 51 & (77.3) \\
\hline 5. Wide excision \& lymph node dissection & 0 & $(0.0)$ & 0 & $(0.0)$ & 1 & $(16.7)$ & 1 & $(1.5)$ \\
\hline 6. None & 4 & $(12.1)$ & 6 & $(22.2)$ & 0 & $(0.0)$ & 10 & $(15.2)$ \\
\hline Total & 33 & & 27 & & 6 & & 66 & $(100)$ \\
\hline
\end{tabular}


margins, the pattern of infiltration, as well as the etiology of the lesion.

The form of the excised tissue should be in the form of a dice, to make it easy to mark the margins.

In case of $\mathrm{BCC}$ of small lesions less than $10 \mathrm{~mm}$ in diameter, excisional biopsy or total excision with a 5 $\mathrm{mm}$ margin from the border the tumor were performed for the treatment. Beside this fresh samples from the tumor, the normal skin peripheral to the tumor and also from normal skin apart from the tumor(s) were taken for the molecular epidemiological study.

For a $\mathrm{BCC}$ with diameter of $10 \mathrm{~mm}$ or over, tumors located on the face and other locations were wideexcised with a margin of $15-20 \mathrm{~mm}$, respectively. The excised tissues were examined histopathologically by pathologists, for evaluating marginal tissue. We did not find any lymph node metastasis in BCC. In Japan, $\mathrm{BCC}$ both on the face and any other body sites was removed by $5 \mathrm{~mm}$ margin, but in case of morphea type of $\mathrm{BCC}$, the margin of excision was $10 \mathrm{~mm}$, since morphea type $\mathrm{BCC}$ was known to invade efficiently during a rather short period. In case of a large facial skin cancer serial excision performed in the setting of Mohs micrographic surgery has been introduced and resulted in excellent cosmesis and function. ${ }^{14}$ This kind of technique might be beneficial in case of the presentation of the skin cancers are already in later stage and relatively big size as frequently encountered in our study, ${ }^{15}$ with the majority of BCC located on the face $(97.6 \%)$. In the future, marginal areas may become smaller and smaller, since longitudinal analysis of operated cases have been extensively done and the data show no difference between $5 \mathrm{~cm}$ and $3 \mathrm{~cm}$ margin even in MM treatment.

For SCC, wide excision of the primary lesions comprises $2 \mathrm{~cm}$ of healthy skin in all directions, with reconstruction using preferably with split thickness skin graft, except if dissection of the tissue disturbs the function of the area.

For MM, wide excision depends upon the pathological staging of the tumor. For the low risk tumors measuring less than $0.76 \mathrm{~mm}$, wide excision with more than $1 \mathrm{~cm}$ free margins proved to be suitable. While for the moderate risk group of tumor thickness between $0.76-1.50 \mathrm{~mm}$, the safety margins required are $2-3 \mathrm{~cm}$ from the tumor borders. But for the high risk group of more than $1.50 \mathrm{~mm}$, we excise with a $3-5 \mathrm{~cm}$ safety margins from the tumor borders.

For enlarged lymph nodes, we perform only dissection if the pathology proved it to contain metastatic tumor cells. Appropriate management of local recurrence, satellites and transit metastases might need isolation perfusion. ${ }^{12}$ So far, malignant melanoma has become great concern for surgical treatment due to its aggressive behavior and the propensity to metastasize through the lymphatic and blood routes. Patients at high risk for metastases should be evaluated by means of x-ray and computed tomography (CT) scans. A modified technique namely resection using CT or ultrasound guided wire localization has been applied to non-palpable metastatic melanoma, which offers several advantages, i.e. minimal surgical dissection, shorter operated times and decreased post operative morbidity. ${ }^{16}$

\section{Acknowledgement}

We appreciate the International Cancer Research Grant system, Monbusho, Japan and the Dean, Faculty of Medicine, University of Indonesia, Jakarta for his approval of the Japan-Indonesia collaborative study, which was initiated by Dean's approval No. 845/PT02.H4.FK/E/97. This work has been supported by the grant no. 09042004, under Ministry of Education, Science, Sports and Culture, Government of Japan and was partly supported by the Indonesian Cancer Foundation, the Jakarta International Cancer Conference Fund and the Terry Fox Foundation, Canada. We would also thank the Director of Dr. Cipto Mangunkusumo National Central General Hospital for technical assistance.

\section{REFERENCES}

1. Glass AG, Hoover RN. The emerging epidemic of melanoma and squamous cell skin cancer. JAMA 1989; 262: 2097-100.

2. Kricker A, Amstrong BK, English DR. Sun exposure and nonmelanocytic skin cancer. Cancer Causes and Control 1994; 5: 369-92.

3. English DR, Amstrong BK, Kricker A, Fleming $\mathrm{C}$. Sunlight and cancer. Cancer Causes and Control 1997; 8: 271-83.

4. Cornain S, Mangunkusumo R, Nasar IM, Prihartono J. Ten most frequent cancers in Indonesia: Pathology based cancer registry data of 1988-1992. In: Cancer Registry in Indonesia. National Cancer Registry Center, Jakarta Coordinating Board, 1997. 
5. Grodstein F, Speizer FE, Hunter DJ. A prospective study of incident squamous cell carcinoma of the skin in the nurses' health study. J Natl Cancer Inst 1995; 87: 1061-6.

6. Suzuki T, Ueda M, Ogata K, Horikoshi T, Munakata N, Ichihashi M. Doses of solar-ultraviolet radiation correlate with skin cancer rates in Japan. Kobe J Med Sci 1996; 42: 375-88.

7. Prihartono J, Budiningsih S, Ohno $\mathrm{Y}$, Hamzah M, Ichihashi M, Poetiray E, et al. Risk factors of skin cancer among Indonesian population. Med J Indones 2000, 9: 100-5.

8. Munakata N. Cornain S, Mulyadi K, Ichihashi M, Prihartono J, Ohno Y, et al. Biologically effective doses of ambient solar-uv radiation in Indonesia and Japan. Med J Indones 2000; 9:123-8.

9. Evert Poetiray. Surgical Procedures Implemented in Skin Cancer Study. Presented in One Day Symposium on Multicenter Study of Epidemiology and Clinicopathology of Skin Cancer (Japan-Indonesia Collaborative Study on Etiology and Clinicopathology of Skin Cancer) July 30, 1997.

10. Essner R and Morton DL. Elective lymph node dissection. In: Lejeune FJ, Chaudhuri PK, Das Gupta TK (Eds).
Malignant Melanoma. Medical and Surgical Management. New York: Mc. Graw-Hill, 1994: 205-14.

11. Storm FK, Mahvi DM. Treatment of primary melanoma. In: Lejeune FJ, Chaudhuri PK, Das Gupta TK (Eds). Malignant Melanoma. Medical and Surgical Management. New York: Mc. Graw-Hill, 1994: 193-203.

12. Schraffordt Koops H, Kroon BBR, Lejeune FJ. Management of local recurrence, satellites and transit metastases of the limbs with isolation perfusion. In: Lejeune FJ, Chaudhuri PK, Das Gupta TK (Eds). Malignant Melanoma. Medical and Surgical Management. New York: Mc. Graw-Hill, 1994: 221-31.

13. Anthony ML. Surgical treatment of nonmelanoma skin cancer. AORN J 2000; 71: 552-4.

14. Schanbacker C, Randle HW. Serial excision of a large facial skin cancer. Dermatol Surg 2000; 26: 381-3.

15. Hamzah M, Ichihashi M, Cipto M, Poetiray E, Mukhtar A, Kanoko M, et al. A clinical study of skin cancer in Indonesian patients. Med J Indones 2000; 9:77-80.

16. Rodriques LK, Habib FA, Wilson M, Turek L, Kerlan RK, Leong SP. Resection of metastatic melanoma following wire localization guided by computed tomography or ultrasound. Melanoma Res 1999; 9: 595-8. 